\title{
Mechanical Behavior of Fresh and Tempered Martensite in a CrMoV-Alloyed Steel Explained by Microstructural Evolution and Strength Modeling
}

\author{
TAO ZHOU, JUN LU, and PETER HEDSTRÖM
}

\begin{abstract}
The mechanical behavior of a wear-resistant $\mathrm{CrMoV}$-alloyed martensitic steel in quenched and tempered conditions has been investigated and correlated with the microstructure. The steel has a combination of ultra-high tensile strength of $2065 \mathrm{MPa}$ and total elongation of $7.4 \mathrm{pct}$ in the as-quenched condition. The strength and ductility of the steel change initially during tempering and thereafter remain quite stable during tempering at either $450{ }^{\circ} \mathrm{C}$ or $550{ }^{\circ} \mathrm{C}$. A good combination of yield strength and total elongation is achieved after tempering at $550{ }^{\circ} \mathrm{C}$ for 2 to 8 hours (about $1300 \mathrm{MPa}$ and $14 \mathrm{pct}$ ). The evolution of the mechanical properties can be mainly related to an initial condition with high density of dislocations (in the order of $10^{15}$ ) and carbon in solid solution, while quite early during tempering, dislocations will start to annihilate and carbide precipitates form. On the other hand, there is a negligible evolution of the effective grain size during tempering. Modeling of the individual strengthening mechanisms and the overall yield strength is in good agreement with the tensile test results, in particular for the tempered samples. Finally, the relatively low yield strength of the fresh martensite, significantly lower than for the tempered conditions, is discussed in relation to the two available theories.
\end{abstract}

https://doi.org/10.1007/s11661-020-05922-x

(c) The Author(s) 2020

\section{INTRODUCTION}

WEAR-RESISTANT steels with excellent combination of strength/hardness and toughness have wide applications, for example tipper bodies, which usually suffer frequent loading and unloading of heavy and sharp rocks, steel scrap, concrete with rebars, etc. This harsh application environment puts significant requirements on the performance of steels used for the tipper bodies. The steels need to have a high resistance towards dent formation and abrasion to increase the lifetime of the product. These property requirements are generally met by combining a martensitic microstructure and precipitation-hardening, which generates a combination of ultra-high strength/hardness and good toughness. ${ }^{[1,2]}$ The diffusionless nature of the martensitic transformation leads to a martensitic microstructure that is defect-rich, with high supersaturation of alloying elements and a hierarchic microstructure consisting of packets, blocks, sub-blocks, and laths. ${ }^{[3-11]}$ The

TAO ZHOU and PETER HEDSTRÖM are with the Department of Materials Science and Engineering, KTH Royal Institute of Technology, 10044 Stockholm, Sweden. Contact e-mail: taozhou@kth.se JUN LU is with the School of Materials Science and Engineering, University of Science and Technology Beijing, Beijng 100083, China.

Manuscript submitted March 4, 2020.

Article published online August 1, 2020 martensitic microstructure is not so ductile and thus a tempering treatment is required subsequently to the quench-hardening. During tempering, the initial martensitic microstructure will evolve towards the equilibrium state of ferrite and carbides. The microstructural evolution can be divided into the following concurrent processes: (i) recovery with dislocation annihilation and residual stress relief $^{[12,13]}$; (ii) precipitation of various carbides heterogeneously at defects like boundaries and dislocations ${ }^{[14-96]}$; (iii) grain growth. ${ }^{[9,10]}$ The clarification of the respective contribution of each phenomenon on mechanical properties is vital for the optimization of wear-resistant steels to extend their service life.

In $\mathrm{CrMoV}$-alloyed martensitic wear-resistant steel, the additions of $\mathrm{Cr}, \mathrm{Mo}$, and $\mathrm{V}$ can increase hardenability during cooling after austenitization and strength/ hardness by precipitation-hardening during tempering. Six possible carbide phases may precipitate in this alloy system depending on alloying content and heat treatment conditions. ${ }^{17-19]}$ Precipitation of these multiple carbides together with the evolution of the martensitic microstructure during tempering determines the mechanical properties of the alloy. The present work aims at exploring the microstructure-property relationship of wear-resistant $\mathrm{CrMoV}$ steels. The mechanical behavior measured by tensile testing of a low-alloy $\mathrm{CrMoV}$ martensitic steel in quenched and tempered conditions is correlated with the quantitative 
microstructural evolution. Modeling of carbide precipitation supports the experimental characterization to understand the microstructural evolution. Finally, yield strength modeling attempts to elucidate the contribution of different microstructural parameters to the yield strength.

\section{METHODOLOGIES}

\section{A. Experimental Procedure}

The investigated material is a commercial alloy with the nominal composition $\mathrm{Fe}-0.32 \mathrm{C}-1.4 \mathrm{Cr}-0.8$ Mo-0.14V-1.1Si-0.8Mn-0.7Ni (wt pct). The martensite start temperature $\left(M_{\mathrm{s}}\right)$ was predicted to be $350{ }^{\circ} \mathrm{C}$ using the model from Rahaman et al., ${ }^{[20]}$ as implemented in ferritico version 2020. ${ }^{[1]}$ Samples with dimensions $1 \times$ $5.6 \times 10 \mathrm{~mm}^{3}$ were firstly solution annealed at $1185^{\circ} \mathrm{C}$ for 1 hour in argon atmosphere in a tube furnace and quenched in brine to room temperature. Thereafter, samples were tempered for various durations from 5 minutes to 10 hours at $450{ }^{\circ} \mathrm{C}$ and $550{ }^{\circ} \mathrm{C}$. These samples were used for the study of microstructural evolution by scanning electron microscopy (SEM) and X-ray diffraction (XRD).

The effective grain size and lath size of martensite evolving with time were characterized by electron backscatter diffraction (EBSD) and electron channeling contrast imaging (ECCI) using a JEOL JSM-7800F SEM equipped with a Bruker e-flash ${ }^{\mathrm{HR}}$ EBSD detector and a JEOL short-range retractable BSE detector. The EBSD data were acquired at an accelerating voltage of $20 \mathrm{kV}$ with a step size of $100 \mathrm{~nm}$. XRD measurements were performed using a Bruker D8 Discover X-ray diffractometer equipped with a LynxEye 1D detector and a sealed tube source with a $\mathrm{Cu}$ anode, operated at $40 \mathrm{kV}$ and $40 \mathrm{~mA}$. The $2 \theta$ range was 40 to $140^{\circ}$ and the step size was $0.01 \mathrm{deg}$. The acquisition time for each step was 6 seconds. A standard $\mathrm{Al}_{2} \mathrm{O}_{3}$ powder sample was used to measure the instrumental peak breadth. The $\mathrm{CuK} \alpha_{2} \mathrm{X}$-rays were stripped and the background was subtracted from each diffraction pattern before fitting the peaks using the pseudo-Voigt function. The peak broadening of cubic crystals is a combined effect of lattice strain broadening and particle size broadening. These two effects can be separated based on the kinematical diffraction theory stating that the particle size broadening is independent of $2 \theta$, whereas the lattice strain broadening depends on $2 \theta .^{[22-24]}$ The modified Williamson-Hall and Warren-Averbach methodologies were used to evaluate the dislocation density from the peak broadening, under the assumption that the strain broadening in martensite is caused by dislocations. The analysis procedure presented in Reference 25 through 27 was adopted.

Vickers hardness measurements using a load of $2000 \mathrm{~g}$ were conducted in a MXT-al microhardness tester. Ten tests were performed on each sample. The average hardness and standard deviation were subsequently calculated. To investigate the tensile behavior of the quenched and tempered samples, larger samples with dimensions $50 \times 5.6 \times 85 \mathrm{~mm}^{3}$ were heat treated using the same parameters as mentioned above but this time in air atmosphere in a box furnace. Thereafter, three tensile test specimens were cut from the middle part of the heat-treated samples by wire electrical discharge machining. The specimens had a rectangular cross section and a dog-bone shape. Gauge length and width were 32 and $8 \mathrm{~mm}$, respectively, and the thickness was $2.2 \mathrm{~mm}$. Three tensile tests per condition were performed at ambient temperature in a universal tensile testing machine with a $200 \mathrm{kN}$ capacity at a constant crosshead speed of $0.01 \mathrm{~mm} / \mathrm{s}$. Tensile elongations were determined using a clip-on extensometer with a measurement distance of $25 \mathrm{~mm}$.

\section{B. Precipitation Modeling}

Precipitation modeling was performed using Langer-Schwartz-Kampmann-Wagner (LSKW) type modeling, calling CALPHAD thermodynamic and kinetic databases, as implemented in the MatCalc software. ${ }^{[28,29]}$ For the setup of the modeling, the selection of the model for the composition of the nuclei and the nucleation sites (see Table I) were based on the literature $^{[30,31]}$ and microstructural observations in a previous work. ${ }^{[32]}$ In Table I, $G^{*}$ refers to the critical energy that must be overcome for nucleation, and ortho-equilibrium (or full equilibrium ${ }^{[33]}$ ) composition means the chemical composition of the nucleus at maximum chemical driving force with respect to all elements. ${ }^{[28]}$ The nucleation model is based on the classical nucleation theory (CNT). The interfacial energy between precipitate and matrix is evaluated utilizing the generalized nearest-neighbor broken-bond $(\mathrm{GBB})$ model $^{[34]}$ and the interface curvature effect is considered by the size-correction model, ${ }^{[35]}$ as implemented in MatCalc. The precipitation modeling applied in the current work was validated by experimental transmission electron microscopy (TEM) data for tempering at $550{ }^{\circ} \mathrm{C}$ from Reference 32 , where four kinds of carbides including $\mathrm{MC}, \mathrm{M}_{3} \mathrm{C}, \mathrm{M}_{6} \mathrm{C}$, and $\mathrm{M}_{7} \mathrm{C}_{3}$ were found to precipitate during tempering up to 100 hours. The same modeling setup was subsequently used to also predict the carbide precipitation at $450{ }^{\circ} \mathrm{C}$ in the present work.

\section{RESULTS AND DISCUSSION}

\section{A. Microstructure of Fresh and Tempered Martensite}

\section{Evolution of effective grain size}

The evolution of the martensitic microstructure is firstly studied by EBSD and ECCI (see Figure 1). Many studies ${ }^{[9,10,36-40]}$ have been carried out trying to determine the effective grain size that determines the strength of lath martensite, however, without a consistent picture. It is widely accepted that high-angle grain boundaries (HAGB) above $15 \mathrm{deg}$ are effective obstacles for slip. Thus, in the present work, the effective grain size of lath martensite was evaluated by the line intercept method with a threshold misorientation of $15 \mathrm{deg}$. The 


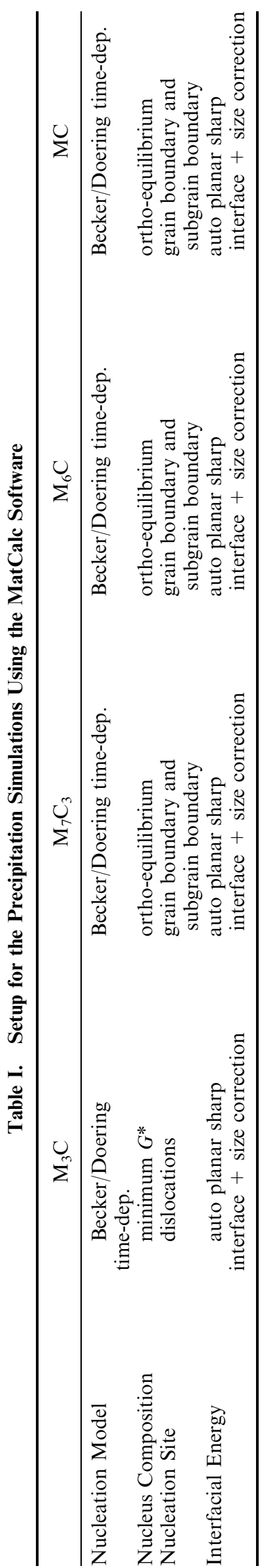

results indicate that the effective grain sizes of the investigated three samples are constant within the experimental error margin, i.e., $1.56 \pm 0.24 \mu \mathrm{m}$ for the as-quenched sample, $1.50 \pm 0.26 \mu \mathrm{m}$ for the 2-hour tempered sample and $1.63 \pm 0.20 \mu \mathrm{m}$ for the 5-hour tempered sample at $550 \mathrm{deg}$. It should be noted that the effective grain size of martensite evaluated here is close to the block width, as blocks are the minimum units of martensite with boundaries above $15 \mathrm{deg}$, whereas sub-block boundary misorientations are about $10 \mathrm{deg}$ and lath boundaries about 2 to 3 deg. ${ }^{[5]}$ The results show that the effective grain size remains quite constant during tempering. This is in agreement with the previous reports ${ }^{[10,14]}$ stating that the size of blocks remains constant during tempering. The ECCI study shows that the laths are coarsening from $278 \pm 21 \mathrm{~nm}$ for the as-quenched condition to $305 \pm 25 \mathrm{~nm}$ for the tempered condition 2 hours at $550{ }^{\circ} \mathrm{C}$ and to $332 \pm 18$ for the tempered condition 5 hours at $550{ }^{\circ} \mathrm{C}$. As the coarsening of the effective grain size ( $>15 \mathrm{deg}$ misorientation) is negligible at $550{ }^{\circ} \mathrm{C}$ and the coarsening of laths is small, it is assumed that softening due to grain coarsening can be neglected not only for the higher temperature $550{ }^{\circ} \mathrm{C}$ but also for the lower temperature $450{ }^{\circ} \mathrm{C}$, where the coarsening should be even less. Thus, grain coarsening has a negligible effect on the evolution of strength during tempering in the present work.

\section{Evolution of dislocation density}

The XRD results for the as-quenched and tempered samples are shown in Figure 2(a). Six bcc iron peaks for each diffraction pattern suggest a single martensite phase. The evolution of peak width during quenching and tempering at $550{ }^{\circ} \mathrm{C}$ tempering conditions is exemplified with a representative 211 diffraction peak (see Figure 2(b)), where the peak width rapidly decreases after tempering 5 minutes at $550{ }^{\circ} \mathrm{C}$ compared to the as-quenched condition. Thereafter, peak width remains almost constant for prolonged tempering up to 5 hours. The evolution of peak broadening of six diffraction peaks $v s$ tempering time at 550 tempering is shown in Figure 2(c) and it is seen that the peak broadening drops drastically at the early stage of tempering (5 minutes) followed by a slow gradual decrease. The peak broadening is defined by $\Delta K=$ $\cos \theta(2 \Delta \theta) / \lambda$, where $\theta$ is the diffraction angle of the peak, $2 \Delta \theta$ is the full width half maximum (FWHM), and $\lambda=0.15406 \mathrm{~nm}$ is the wavelength of $\mathrm{CuK}_{\alpha 1}$ X-rays. After tempering for 5 minutes at $550{ }^{\circ} \mathrm{C}$, close to $40 \mathrm{pct}$ of the dislocations are annihilated. The dislocation density of the as-quenched condition is $(2.9 \pm 0.38)$ $\times 10^{15} \mathrm{~m}^{-2}$ and after tempering for 5 minutes it is $(1.8 \pm$ $0.31) \times 10^{15} \mathrm{~m}^{-2}$. The dislocation density further gradually decreases to $(1.3 \pm 0.11) \times 10^{15} \mathrm{~m}^{-2}$ after tempering up to 5 hours. The evolution with decreasing dislocation density is slower at the lower tempering temperature as seen in Figure 2(d). The dislocation densities of all samples are nonetheless high, in the order of $10^{15}$. This high dislocation density is important for the properties of the steel, affecting both strength and ductility. [41] 

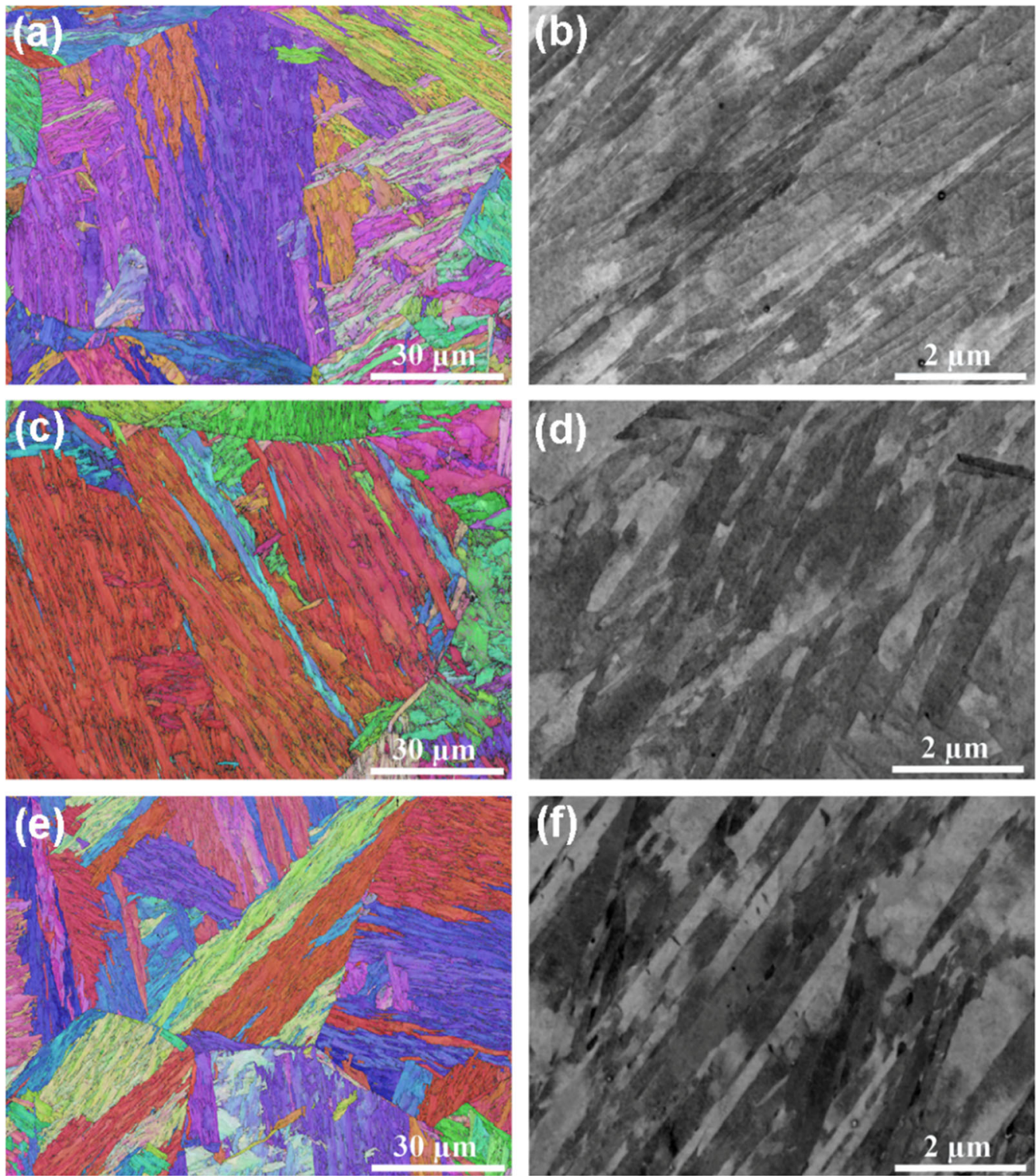

Fig. 1-Electron backscatter diffraction (EBSD) images of inverse pole figure + band contrast (IPF + BC) and electron channeling contrast images (ECCI): $(a$ and $b)$ as-quenched sample, $\left(c\right.$ and $d$ ) tempering 2-hour sample at $550{ }^{\circ} \mathrm{C}$, and $(e$ and $f)$ tempering 5 -hour sample at $550{ }^{\circ} \mathrm{C}$.

\section{Carbide precipitation evolution}

The precipitation of $\mathrm{M}_{3} \mathrm{C}, \mathrm{M}_{7} \mathrm{C}_{3}, \mathrm{M}_{6} \mathrm{C}$, and $\mathrm{MC}$ carbides simulated by the LSKW-based modeling at 550 ${ }^{\circ} \mathrm{C}$ is in quite good agreement with the experimental data, except a slight underestimation of the size of the $\mathrm{M}_{6} \mathrm{C}$ (see Figure 3(a)). The transition from metastable $\mathrm{M}_{3} \mathrm{C}$ to stable carbides is also captured by the modeling. The volume fraction plots (see Figure 3(b)) indicate that the $\mathrm{M}_{3} \mathrm{C}$ starts to dissolve before 10 hours and after about 100 hours $\mathrm{M}_{7} \mathrm{C}_{3}$ starts to dominate. In contrast, $\mathrm{M}_{6} \mathrm{C}$ and $\mathrm{MC}$ have negligible volume fractions, consistent with the experimental characterization by TEM and XRD. ${ }^{[32]}$

The good quantitative agreement between experiments ${ }^{[32]}$ and modeling of cementite at $550{ }^{\circ} \mathrm{C}$ suggests that it could also be successful to predict similar conditions. Therefore, we apply the same modeling setup to simulate cementite precipitation also at $450{ }^{\circ} \mathrm{C}$. It is found that also at $450{ }^{\circ} \mathrm{C}$ tempering cementite is the only dominant carbide up until 100 hours. The results from the modeling of cementite precipitation at both tempering temperatures are presented in Figure 4 for comparison. The difference between the two temperatures is that the increase of cementite mean radius, volume fraction, and number density is shifted towards longer tempering times due to the lower diffusivity of carbon at the lower temperature.

\section{B. Mechanical Behavior in Tensile and Hardness Testing}

The true stress-strain curves, work hardening rate, yield strength $\left(0.2\right.$ pct proof stress, $\left.\mathrm{Rp}_{0.2}\right)$, ultimate tensile strength (UTS), total elongation $\left(e_{\text {total }}\right)$, and uniform elongation $\left(e_{\text {uniform }}\right)$ are determined based on 


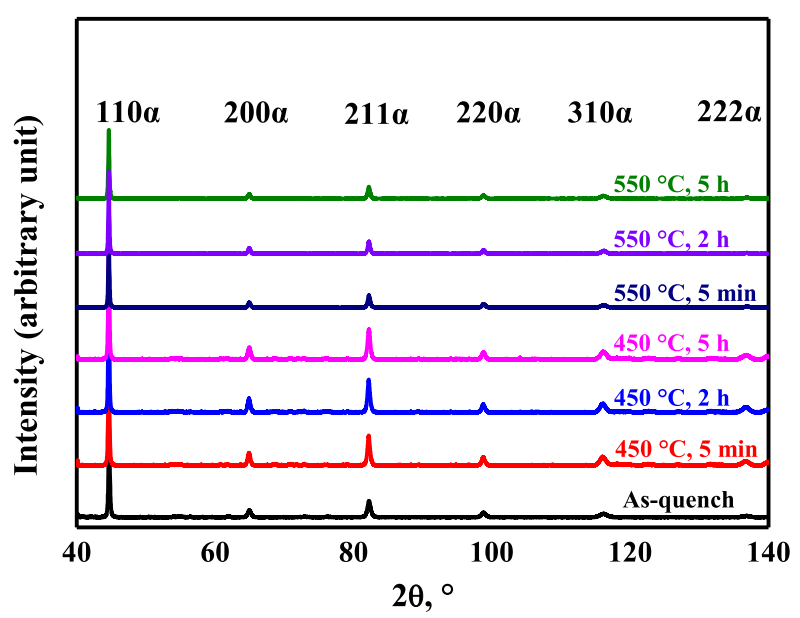

(a)

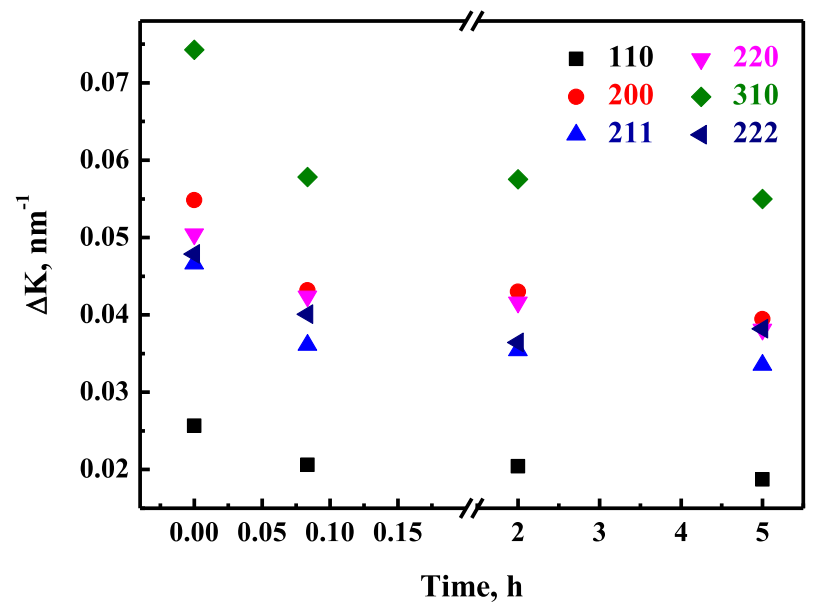

(c)

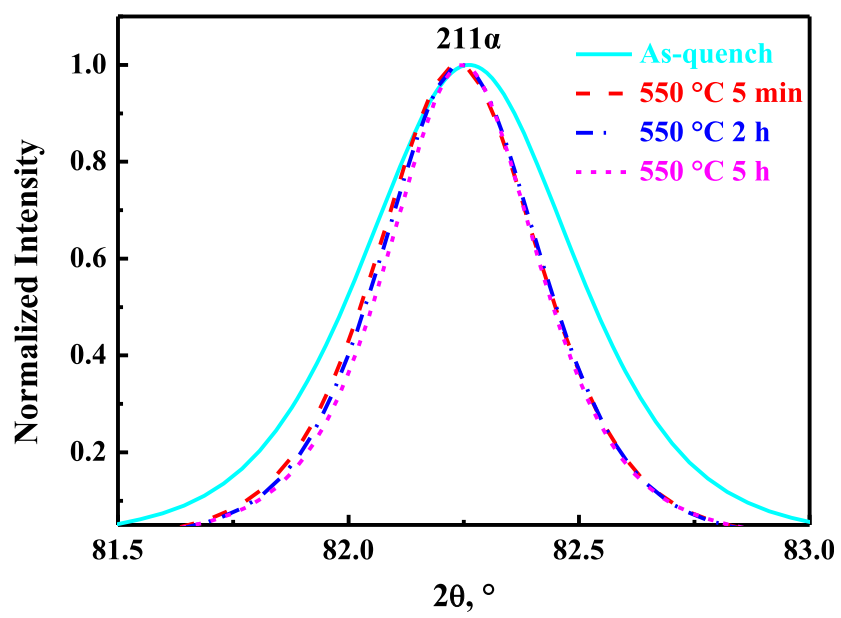

(b)

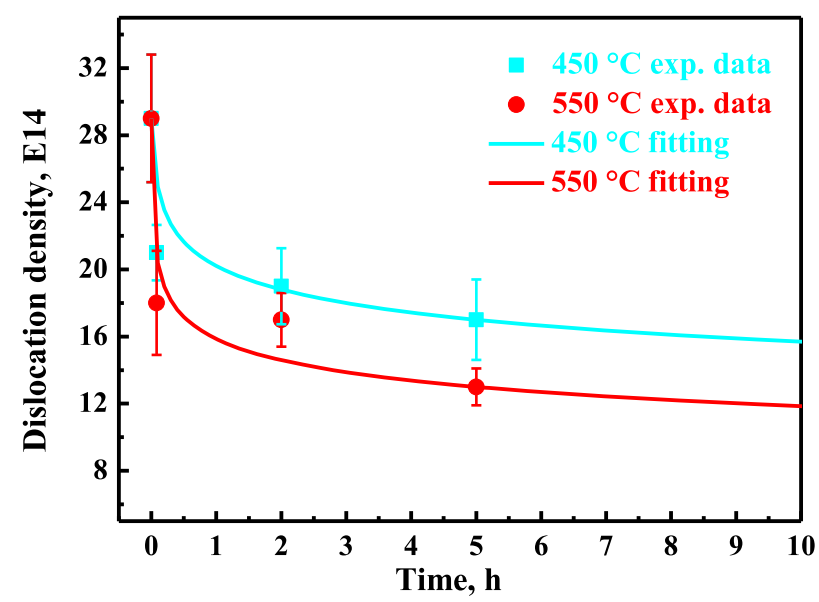

(d)

Fig. 2-Dislocation density from XRD measurements: (a) XRD spectra of the as-quenched sample and tempered samples, (b) comparison of 211 peak of as-quenched and tempered samples at $550{ }^{\circ} \mathrm{C},(c)$ peak broadening of six peaks $v s$ tempering time at $550{ }^{\circ} \mathrm{C}$, and $(d)$ dislocation density vs tempering time.

the nominal stress-strain curves for as-quenched as well as $450{ }^{\circ} \mathrm{C}$ and $550{ }^{\circ} \mathrm{C}$ tempered conditions (see Figure 5). The as-quenched sample has an excellent combination of UTS $(2065 \mathrm{MPa})$ and $e_{\text {total }}(7.4 \mathrm{pct})$. It is noted that the onset of plastic deformation for the as-quenched sample is earlier $\left(\mathrm{Rp}_{0.2}=1166 \mathrm{MPa}\right)$ than for the tempered samples. After the early yielding of the as-quenched samples they experience a significant work hardening until the UTS at $2065 \mathrm{MPa}$, i.e., the strength ratio $\left(\mathrm{Rp}_{0.2} / \mathrm{UTS}\right)$ is merely 0.56 . The early yielding is typical for single-phase fresh lath martensite, and several mechanisms have been proposed to explain this behavior. One explanation is based on the non-uniform distribution of carbon. ${ }^{[42]}$ Since martensitic transformation occurs over a range of temperature, auto-tempering happens to the fresh martensite resulting in the segregation of carbon atoms around lath boundaries. ${ }^{[32,43]}$ Carbon-depleted regions having lower strength level may yield earlier than carbon-rich regions. This kind of carbon dispersion also occurs during tempering of martensite and it is not clear why tempered martensite would not experience early yielding in such case. Another possible mechanism is based on the 'free' dislocations ${ }^{[44]}$ formed during the martensitic transformation. These dislocations are easily moved by applying a low stress, resulting in an early plastic deformation. Another explanation is based on the residual stresses in the fresh martensitic microstructure also created during the martensitic transformation, where the plastic flow initiates firstly in the matrix where the local residual stress is aligned to add to the applied stress. ${ }^{[45,46]}$ Both the dislocations and residual stresses could be annihilated or reduced during tempering, so both phenomena would become less prominent in the tempered samples. It is, hence, quite possible that both mechanisms are acting and so far there is no experimental evidence for either mechanism being more significant. The early yielding behavior of the fresh martensite makes it difficult to model the yield strength of both fresh and tempered martensite using the same set of semi-empirical strength models, though it is possible to get agreement with experiments using more sophisticated 


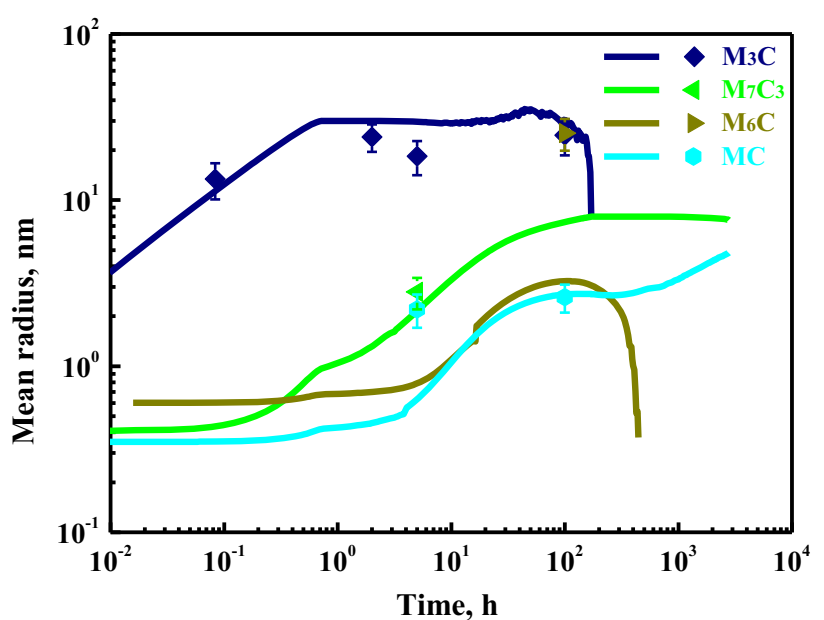

(a)

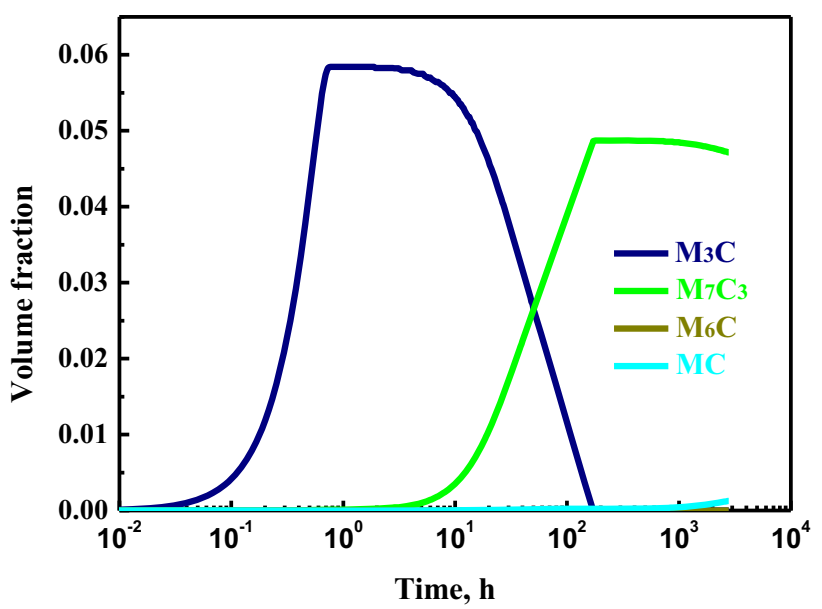

(b)

Fig. 3-The simulation of carbides precipitation in a multi-component system Fe-0.32C-1.4Cr-0.8Mo-0.14V-1.1Si-0.8Mn$0.7 \mathrm{Ni}$ (wt pct) at $550{ }^{\circ} \mathrm{C}$ by using the MatCalc software (version 5.52.1010): (a) mean radius of precipitates, compared with the collected experimental data and $(b)$ volume fraction of precipitates.

treatments such as crystal plasticity modeling. ${ }^{[45]}$ However, for universal applicability it is necessary to improve the understanding of the early yielding and it would also be beneficial to develop a more simplistic modeling approach for materials design applications.

After tempering, the effects of mobile dislocations and micro-stresses are no longer prominent. Most of the remaining dislocations should be pinned by each other and by carbon segregation as Cottrell atmospheres ${ }^{[43]}$ and by cementite precipitates. These pinned dislocations in the tempered samples need larger stress to move, so the tempered samples have relatively higher yield strength. The work hardening rate of the as-quenched sample is significantly higher than those of the tempered samples (see Figures 5(b) and (d)). There are two explanations for this phenomenon: (i) rapid dislocation multiplication caused by deformation ${ }^{[4]}$ and (ii) sequential yielding of regions with different strength levels. ${ }^{[42]}$ At the later stage of plastic deformation before necking,

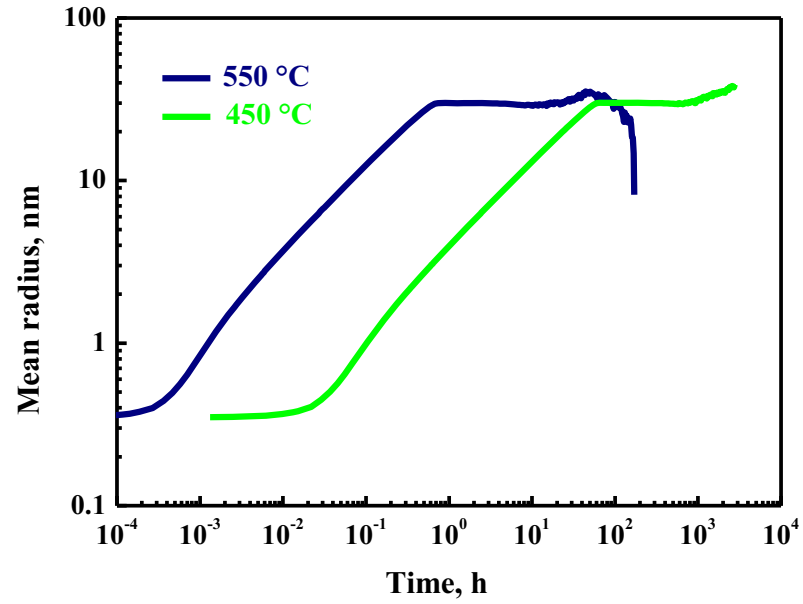

(a)

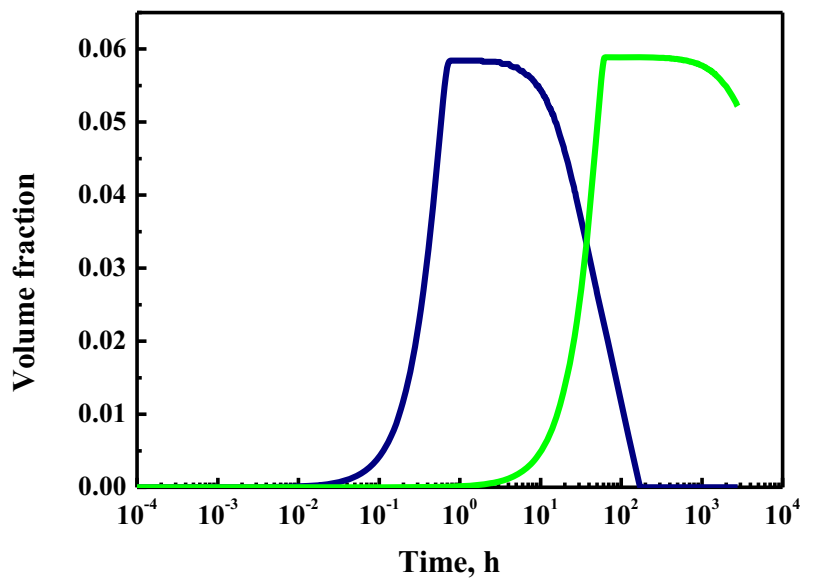

(b)

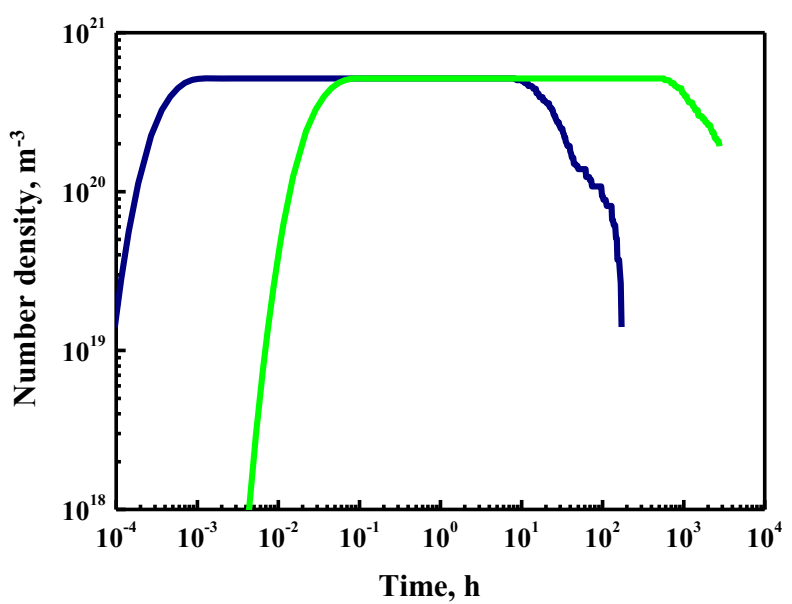

(c)

Fig. 4-The simulation of cementite precipitation at $450{ }^{\circ} \mathrm{C}$ and 550 ${ }^{\circ} \mathrm{C}$ in a multi-component system $\mathrm{Fe}-0.32 \mathrm{C}-1.4 \mathrm{Cr}-0.8 \mathrm{Mo}-0.14 \mathrm{~V}-$ $1.1 \mathrm{Si}-0.8 \mathrm{Mn}-0.7 \mathrm{Ni}$ (wt pet) by using the MatCalc software (version 5.52.1010): (a) mean radius, $(b)$ volume fraction, and $(c)$ number density.

the work hardening rate of the as-quenched sample rapidly decreases and becomes similar to those of the tempered samples at strain $\sim 0.045$ in Figure 5(b). This 


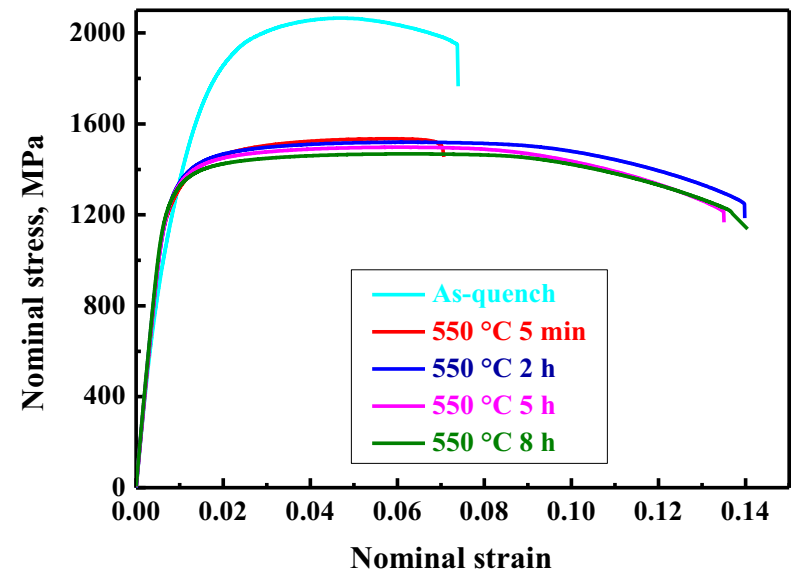

(a)

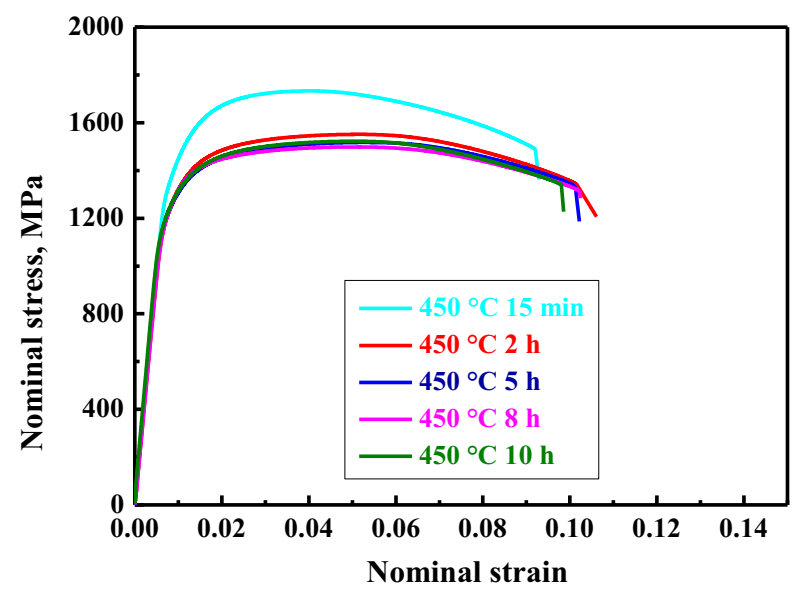

(c)

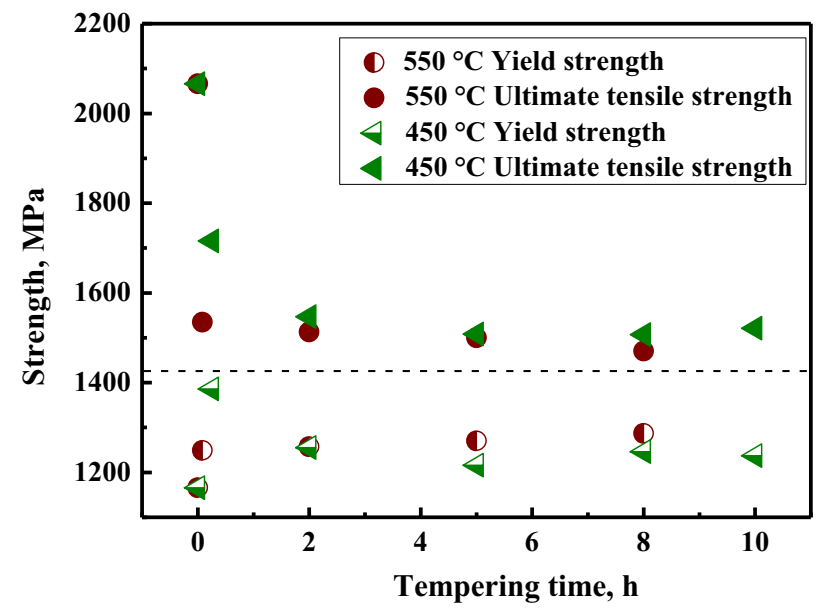

(e)

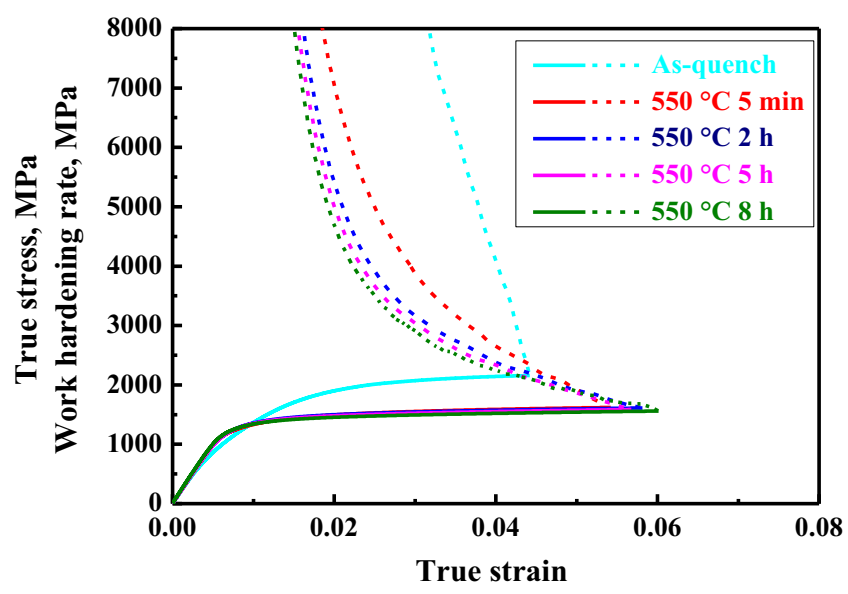

(b)

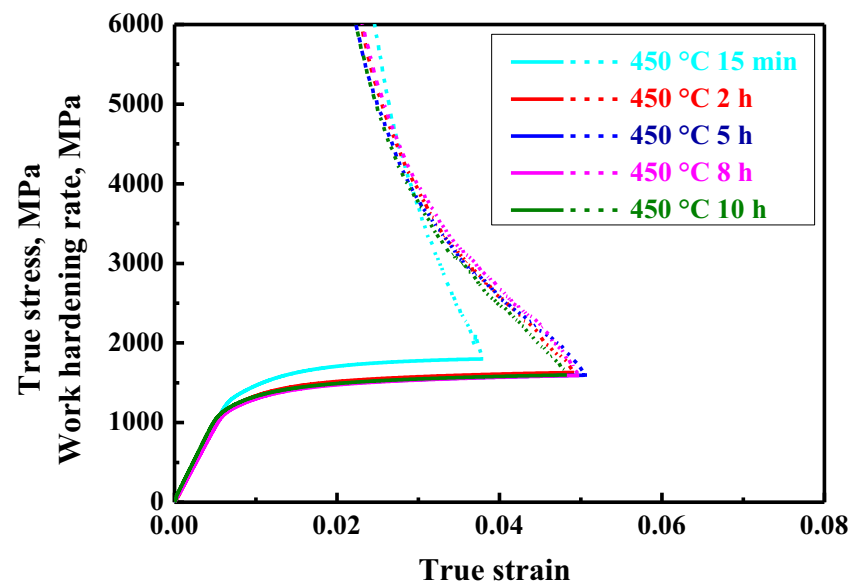

(d)

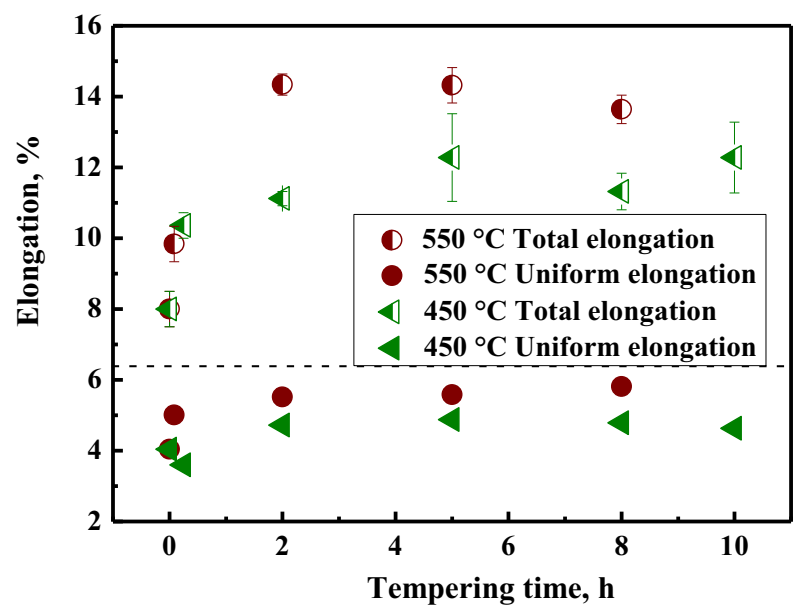

(f)

Fig. 5- (a) Nominal stress-strain curves of the as-quenched and tempered samples at $550{ }^{\circ} \mathrm{C}$ and $(b)$ the corresponding true stress-strain curves and work hardening rate, $(c)$ nominal stress-strain curves of tempered samples at $450{ }^{\circ} \mathrm{C}$ and $(d)$ the corresponding true stress-strain curves and work hardening rate, $(e)$ yield strength and tensile strength $v s$ tempering time, and $(f)$ total elongation and uniform elongation $v s$ tempering time.

may be due to dislocation annihilation (usually called dynamic recovery ${ }^{[48]}$ ) or the concurrent plastic deformation of all the regions. It is noted from the tensile results that the steel holds almost constant strength and ductility for 2-8 hours tempering at $550{ }^{\circ} \mathrm{C}$ and $2-10$ hours tempering at $450{ }^{\circ} \mathrm{C}$. Both the yield strength and tensile strength after $450{ }^{\circ} \mathrm{C}$ and $550{ }^{\circ} \mathrm{C}$ tempering for the same time ranging from 2 to 8 hours are similar. The stable mechanical properties of the tempered samples plausibly result from the decrease of dislocation 
strengthening due to dislocation annihilation, and reduced solid solution strengthening by carbon which are counteracted by the precipitation strengthening when nanoscale cementite precipitation occurs. The total elongation and uniform elongation of the $550{ }^{\circ} \mathrm{C}$ tempered samples are larger than the counterparts after tempering at $450{ }^{\circ} \mathrm{C}$. This could be due to the larger recovery at the higher temperature with less significant residual stresses and fewer dislocations, causing less stress concentration and thus higher ductility. ${ }^{[49]}$

\section{Microstructure and Mechanical Property Relation}

The Vickers hardness $v s$ tempering time at the two tempering temperatures is presented in Figure 6. The results show a similar trend at the two temperatures. The hardness first sharply decreases at the early stage of tempering, before becoming stable for a fairly long tempering time, and finally it slightly decreases. The as-quenched sample shows the highest hardness of 677 $\pm 13 \mathrm{HV}$, followed by a sharp decrease after tempering for 5 minutes to $469 \pm 11 \mathrm{HV}$ at $550{ }^{\circ} \mathrm{C}$, whereas the final hardness at $450{ }^{\circ} \mathrm{C}$ is $535 \pm 11 \mathrm{HV}$. This first decreasing stage is caused by the recovery process during tempering, i.e., the annihilation of dislocations and residual stresses which reduce the obstructions for dislocation glide, making the material softer. It is noteworthy that the plastic strain during hardness measurement $(\sim 8 \mathrm{pct})^{[50]}$ is significantly larger than the 0.2 pct proof strain during tensile testing, so the hardness trend should not be directly comparable to the trend of the 0.2 pct proof strength from quenched and tempered conditions. After 5 minutes of tempering at $550{ }^{\circ} \mathrm{C}$ cementite should have nucleated (Figure 4) but its hardening effect is fairly small, usually it is neglected. However, thereafter when a high number of cementite particles have formed and grown (see Figure 4) it seems to counteract the strength decrease due to further dislocation annihilation and less solid solution hardening from carbon. This is witnessed as a slight increase in the hardness plot after the initial decrease at $550^{\circ} \mathrm{C}$, but

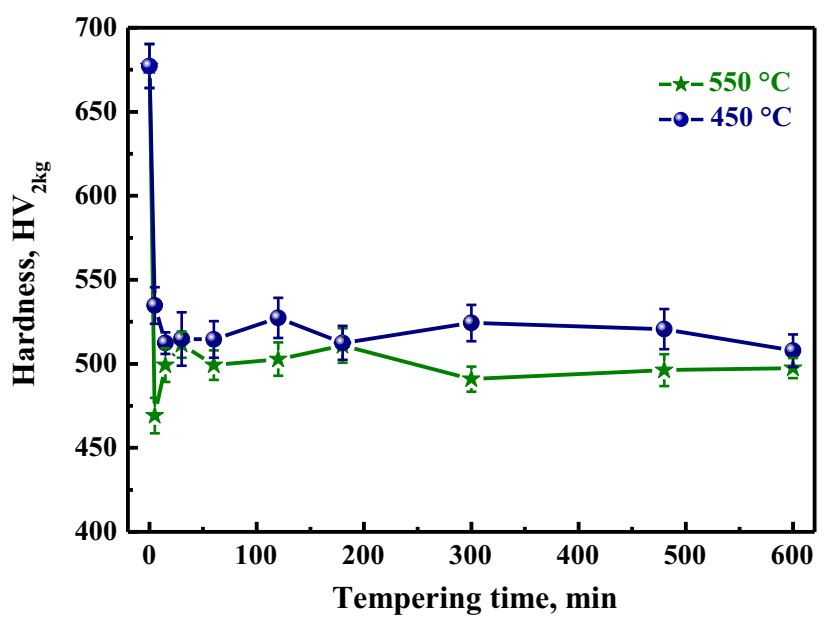

Fig. 6-Vickers micro-hardness of as-quenched and tempered samples for 0 to 10 hours at $450{ }^{\circ} \mathrm{C}$ and $550{ }^{\circ} \mathrm{C}$. it is not seen for the $450{ }^{\circ} \mathrm{C}$ tempering, possibly due to the delayed precipitation of cementite at the lower temperature. It should be noted that these results are non-conclusive, but give an indication that the effect of cementite precipitates should be considered to accurately predict hardness and strength of martensite tempered at a fairly low temperature, since nanoscale cementite can also provide a significant strengthening effect. ${ }^{[51]}$ Overall, the hardness of the steel is quite stable during tempering at $450{ }^{\circ} \mathrm{C}$ and $550{ }^{\circ} \mathrm{C}$. This is consistent with the aforementioned strength results.

Overall, the evolution of dislocation density and cementite precipitation correlated with the carbon in solid solution are the main factors controlling the mechanical property evolution of martensite in this work. The sharp decrease of dislocation density at the very early stage of tempering at $550{ }^{\circ} \mathrm{C}$ (Figure $2(\mathrm{~d})$ ) partly leads to the decrease of the hardness and ultimate tensile strength, while thereafter the maintained high dislocation density contributes to the stable properties upon further tempering. With respect to precipitation, cementite is in the growth stage after 5 minutes while it is in a quite stable stage for 2 to 8 hours of tempering at $550{ }^{\circ} \mathrm{C}$ (Figure 4). The increase in volume fraction of cementite between 5 minutes and 2 hours tempering at $550{ }^{\circ} \mathrm{C}$ could contribute to increasing precipitation-hardening, which explains the increase in hardness after 5 minutes of tempering (Figure 6). Furthermore, since most carbon exist in the form of cementite and the mean radius and volume fraction of cementite are stable during extended tempering, it is reasonable to presume that carbon depletion in the matrix and precipitation play a negligible role in the evolution of strength at this stage. This, together with the almost constant dislocation density after 2 hours tempering at $550{ }^{\circ} \mathrm{C}$, inhibits the softening of the material, which results in stable mechanical properties. In the case of tempering at $450{ }^{\circ} \mathrm{C}$, cementite is in the growth stage for tempering between 15 minutes and 10 hours. The volume fraction of cementite is fairly low during this time, resulting in lower precipitation strengthening effect compared to the $550{ }^{\circ} \mathrm{C}$ tempered samples. This could be another reason why the strength is maintained for longer tempering times at $450{ }^{\circ} \mathrm{C}$, in addition to the effect of the maintained higher dislocation density at 450 ${ }^{\circ} \mathrm{C}$ compared to at $550{ }^{\circ} \mathrm{C}$.

To analyze the microstructural effects on the yield strength, the individual microstructural contributions to the yield strength are modeled. Firstly, as the effective grain size remains constant, grain boundary strengthening is assumed constant and is calculated with the average unit size $(\sim 1.56 \mu \mathrm{m})$ for all the measured samples. This contribution is about $168 \mathrm{MPa}$ following the Hall-Petch equation ${ }^{[39,52,53]}$.

$$
\Delta \sigma_{\mathrm{gb}}=\frac{k_{\mathrm{HP}}}{\sqrt{d}}\left(k_{\mathrm{HP}}=0.21 \mathrm{MPa} \mathrm{m}^{1 / 2}\right) .
$$

Secondly, the carbon content in solid solution is evaluated by considering the nominal composition and subtracting the carbon bound to the cementite 
Table II. The Strengthening Coefficients of Solid Solution Strengthening ${ }^{[43,54]}$ and the Atomic Fraction of Elements of the Studied Material

\begin{tabular}{llllllll}
\hline Element & \multicolumn{1}{c}{$\mathrm{C}$} & \multicolumn{1}{c}{$\mathrm{Si}$} & $\mathrm{Mn}$ & $\mathrm{Cr}$ & $\mathrm{Ni}$ & $\mathrm{Mo}$ & $\mathrm{V}$ \\
\hline$\beta_{i}$ & 2877 & 732 & 213 & 434 & 334 & 2143 \\
$x_{i}$ & 0.0148 & 0.0223 & 0.0083 & 0.0143 & 0.0065 & 0.0045 & 0.0015 \\
\hline
\end{tabular}

Table III. Summary of Individual Strengthening Mechanisms and Yield Strengths (MPa)

\begin{tabular}{|c|c|c|c|c|c|c|c|c|c|c|}
\hline $\begin{array}{l}\text { Tempering } \\
\text { Time }\end{array}$ & Quench & $\begin{array}{l}550^{\circ} \mathrm{C} 5 \\
\text { Minutes }\end{array}$ & $\begin{array}{c}550{ }^{\circ} \mathrm{C} 2 \\
\text { Hours }\end{array}$ & $\begin{array}{c}550{ }^{\circ} \mathrm{C} 5 \\
\text { Hours }\end{array}$ & $\begin{array}{c}550{ }^{\circ} \mathrm{C} 8 \\
\text { Hours }\end{array}$ & $\begin{array}{c}450{ }^{\circ} \mathrm{C} 15 \\
\text { Minutes }\end{array}$ & $\begin{array}{c}450^{\circ} \mathrm{C} 2 \\
\text { Hours }\end{array}$ & $\begin{array}{c}450^{\circ} \mathrm{C} 5 \\
\text { Hours }\end{array}$ & $\begin{array}{c}450{ }^{\circ} \mathrm{C} 8 \\
\text { Hours }\end{array}$ & $\begin{array}{c}450{ }^{\circ} \mathrm{C} 10 \\
\text { Hours }\end{array}$ \\
\hline $\begin{array}{l}\Delta \sigma_{\mathrm{gb}} \\
\quad \text { (Model) }\end{array}$ & 168 & 168 & 168 & 168 & 168 & 168 & 168 & 168 & 168 & 168 \\
\hline$\Delta \sigma_{\mathrm{ss}}$ & 398 & 390 & 191 & 196 & 204 & 398 & 397 & 394 & 389 & 386 \\
\hline$\Delta \sigma_{0}$ & 50 & 50 & 50 & 50 & 50 & 50 & 50 & 50 & 50 & 50 \\
\hline $\begin{array}{l}\Delta \sigma_{\text {disl }} \\
\quad \text { (Model) }\end{array}$ & 761 & 645 & 540 & 510 & 494 & 678 & 613 & 583 & 567 & 560 \\
\hline $\begin{array}{l}\Delta \sigma_{\mathrm{pcpt}} \\
\quad \text { (Model) }\end{array}$ & 0 & 135 & 348 & 348 & 346 & 29 & 77 & 114 & 139 & 150 \\
\hline$\sigma_{\mathrm{y}}($ Model $)$ & 1227 & 1245 & 1325 & 1295 & 1279 & 1173 & 1156 & 1163 & 1171 & 1174 \\
\hline$\sigma_{\mathrm{y}}($ Exp. $)$ & 1166 & 1249 & 1257 & 1270 & 1287 & 1386 & 1255 & 1216 & 1246 & 1237 \\
\hline
\end{tabular}

Table IV. The Quantitative Microstructural Parameters Used for Strength Modeling

\begin{tabular}{|c|c|c|c|c|c|c|c|c|c|c|}
\hline $\begin{array}{l}\text { Tempering } \\
\text { Time }\end{array}$ & Quench & $\begin{array}{l}550{ }^{\circ} \mathrm{C} 5 \\
\text { Minutes }\end{array}$ & $\begin{array}{c}550^{\circ} \mathrm{C} \\
2 \\
\text { Hours }\end{array}$ & $\begin{array}{c}550^{\circ} \mathrm{C} \\
5 \\
\text { Hours }\end{array}$ & $\begin{array}{c}550^{\circ} \mathrm{C} \\
8 \\
\text { Hours }\end{array}$ & $\begin{array}{c}450^{\circ} \mathrm{C} 15 \\
\text { Minutes }\end{array}$ & $\begin{array}{c}450{ }^{\circ} \mathrm{C} 2 \\
\text { Hours }\end{array}$ & $\begin{array}{c}450{ }^{\circ} \mathrm{C} 5 \\
\text { Hours }\end{array}$ & $\begin{array}{c}450^{\circ} \mathrm{C} \\
8 \\
\text { Hours }\end{array}$ & $\begin{array}{c}450{ }^{\circ} \mathrm{C} \\
10 \\
\text { Hours }\end{array}$ \\
\hline $\begin{array}{l}\text { Effective Grain } \\
\quad \text { Size, } d(\mu \mathrm{m})\end{array}$ & 1.56 & 1.56 & 1.56 & 1.56 & 1.56 & 1.56 & 1.56 & 1.56 & 1.56 & 1.56 \\
\hline $\begin{array}{l}\text { Dislocation } \\
\text { Density, } \rho(\times \\
\left.10^{15}\right)\end{array}$ & 2.90 & 2.08 & 1.46 & 1.30 & 1.22 & 2.30 & 1.88 & 1.70 & 1.61 & 1.57 \\
\hline $\begin{array}{l}\text { Mean Radius } \\
\text { of } \mathrm{M}_{3} \mathrm{C}, r \\
(\mathrm{~nm})\end{array}$ & 0 & 11.3 & 30.0 & 29.7 & 29.0 & 1.8 & 5.7 & 9.1 & 11.7 & 13.0 \\
\hline $\begin{array}{l}\text { Volume Frac- } \\
\text { tion of } \mathrm{M}_{3} \mathrm{C} \text {, } \\
f\end{array}$ & 0 & 0.0031 & 0.0583 & 0.0575 & 0.0558 & $1.30 \times 10^{-5}$ & $4.12 \times 10^{-4}$ & $1.68 \times 10^{-3}$ & 0.0035 & 0.0048 \\
\hline
\end{tabular}

precipitates at each tempering condition. The substitutional elements are considered constant in the matrix. Thereafter, solid solution strengthening is evaluated to be 191 to $398 \mathrm{MPa}$ depending on the tempering condition following Eq. [2], ${ }^{[54]}$ and using the strengthening coefficients presented in Table II.

$$
\Delta \sigma_{\mathrm{ss}}=\left(\sum_{i} \beta_{i}^{2} x_{i}\right)^{1 / 2}
$$

Thirdly, dislocation strengthening provides a major contribution to the high strength of the steel within a range of 494 to $761 \mathrm{MPa}$ using the fitted results for the dislocation density from the XRD measurements (Figure 2(d)) and by the following equation ${ }^{[36]}$ :

$$
\begin{aligned}
\Delta \sigma_{\text {disl }} & =M \alpha G b \sqrt{\rho} \\
(M & =3, \quad \alpha=0.25, \quad G=76 \mathrm{GPa}, \quad b=0.248 \mathrm{~nm}) .
\end{aligned}
$$




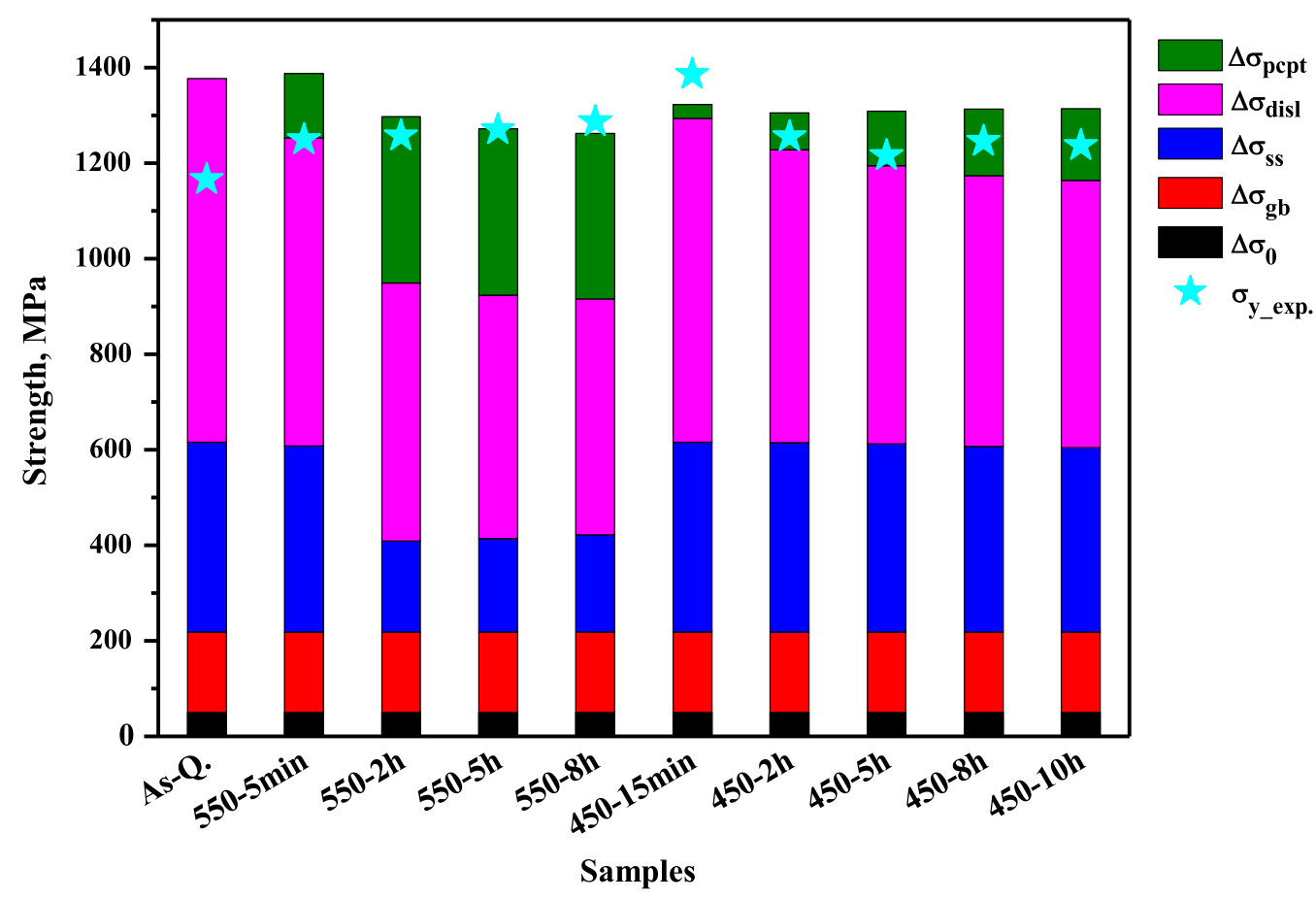

Fig. 7-Modeling of yield strength through adding the individual strengthening mechanisms in the bar charts, compared to the experimental results indicated by stars.

Fourthly, the precipitation strengthening is evaluated considering the Orowan mechanism, as cementite is usually incoherent with the Fe bcc matrix. Precipitate mean radius and volume fraction come from the precipitation modeling (Figure 4). The large volume fraction of cementite with nanoscale size has an evaluated precipitation strengthening of maximum $348 \mathrm{MPa}$, which is in agreement with prior work. ${ }^{[31,55]}$ The precipitation strengthening are evaluated using the following equations ${ }^{[56]}$ :

$$
\begin{gathered}
\Delta \sigma_{\mathrm{pcpt}}=M \frac{0.4 G b}{\pi \sqrt{1-v}} \frac{\ln \left(2 \sqrt{\frac{2}{3}} r / b\right)}{\lambda} \quad(v=0.3), \\
\lambda=2 \sqrt{\frac{2}{3}} r\left(\sqrt{\frac{\pi}{4 f}}-1\right) .
\end{gathered}
$$

All the individual strength contributions are summarized in Table III and the corresponding microstructural parameters are summarized in Table IV. Through comparison of the modeling and tensile test results for yield strength in Figure 7, it is found that the modeling agrees quite well with the experiments for both the $450{ }^{\circ} \mathrm{C}$ and the $550{ }^{\circ} \mathrm{C}$ tempered samples. The tested yield strength $\left(\mathrm{Rp}_{0.2}\right)$ of the as-quenched condition is distinctly lower than the result from the modeling. This is expected considering the early plastic yielding of fresh martensite as discussed earlier. The effects of residual stresses and 'free' dislocations on the yield strength cannot be accounted for by the current strength models. It should be noted that the presence of residual stresses contributes to the high UTS of the as-quenched sample, but decreases the yield strength $\left(\mathrm{Rp}_{0.2}\right)$.

\section{CONCLUSIONS}

(1) The studied CrMoV-alloyed steel shows an excellent combination of strength and ductility after tempering at $550{ }^{\circ} \mathrm{C}$ for $2-8$ hours, with yield strength of about $1300 \mathrm{MPa}$ and total elongation of about 14 pet.

(2) The early plastic yielding phenomenon of fresh lath martensite is discussed considering the two mechanisms regarding 'free' dislocations and residual stresses. In the modeling of the yield strength $\left(\mathrm{Rp}_{0.2}\right)$ it is difficult to account for these mechanisms for both fresh and tempered martensite using the same set of semi-empirical models.

(3) The modeling of precipitation using LSKW approach, calling CALPHAD thermodynamic and kinetic databases, is in quite good agreement with the experimental results considering the precipitating phases and their quantities as well as transition between them.

(4) The modeling of yield strength, incorporating quantitative microstructural parameters from characterization and modeling, is in good agreement with the results from tensile testing for either $450{ }^{\circ} \mathrm{C}$ or $550{ }^{\circ} \mathrm{C}$ tempering conditions. 


\section{ACKNOWLEDGMENTS}

Open access funding provided by Royal Institute of Technology. This work was performed within the VINN Excellence Center Hero-m 2i, financed by VINNOVA, the Swedish Governmental Agency for Innovation Systems, Swedish industry and KTH Royal Institute of Technology. The authors are grateful to Magnus Andersson from SSAB for providing the material.

\section{OPEN ACCESS}

This article is licensed under a Creative Commons Attribution 4.0 International License, which permits use, sharing, adaptation, distribution and reproduction in any medium or format, as long as you give appropriate credit to the original author(s) and the source, provide a link to the Creative Commons licence, and indicate if changes were made. The images or other third party material in this article are included in the article's Creative Commons licence, unless indicated otherwise in a credit line to the material. If material is not included in the article's Creative Commons licence and your intended use is not permitted by statutory regulation or exceeds the permitted use, you will need to obtain permission directly from the copyright holder. To view a copy of this licence, visit http://creat ivecommons.org/licenses/by/4.0/.

\section{REFERENCES}

1. N. Kamikawa, K. Sato, G. Miyamoto, M. Murayama, N. Sekido, K. Tsuzaki, and T. Furuhara: Acta Mater., 2016, vol. 83, pp. 383-96.

2. T. Zhou, R.P. Babu, J. Odqvist, H. Yu, and P. Hedström: Mater. Des., 2018, vol. 143, pp. 141-49.

3. S. Morito, H. Saito, T. Ogawa, T. Furuhara, and T. Maki: ISIJ Int., 2005, vol. 45, pp. 91-94.

4. S. Morito, X. Huang, T. Furuhara, T. Maki, and N. Hansen: Acta Mater., 2006, vol. 54, pp. 5323-31.

5. S. Morito, H. Tanaka, R. Konishi, T. Furuhara, and T. Maki: Acta Mater., 2003, vol. 51, pp. 1789-99.

6. S. Morito, Y. Adachi, and T. Ohba: Mater. Trans., 2009, vol. 50, pp. 1919-23.

7. L. Morsdorf, C.C. Tasan, D. Ponge, and D. Raabe: Acta Mater., 2015, vol. 95, pp. 366-77.

8. H. Kitahara, R. Ueji, N. Tsuji, and Y. Minamino: Acta Mater., 2006, vol. 54, pp. 1279-88.

9. C. Zhang, Q. Wang, J. Ren, R. Li, M. Wang, F. Zhang, and K. Sun: Mater. Sci. Eng. A, 2012, vol. 534, pp. 339-46.

10. C. Zhang, Q. Wang, J. Ren, R. Li, M. Wang, F. Zhang, and Z. Yan: Mater. Des., 2012, vol. 36, pp. 220-26.

11. A. Stormvinter, G. Miyamoto, T. Furuhara, P. Hedström, and A. Borgenstam: Acta Mater., 2012, vol. 60, pp. 7265-74.

12. T. Zhou, J. Faleskog, R.P. Babu, J. Odqvist, H. Yu, and P. Hedström: Mater. Sci. Eng. A, 2019, vol. 745, pp. 420-28.

13. J. Klemm-Toole, J. Benz, I. Vieira, A.J. Clarke, S.W. Thompson, and K.O. Findley: Mater. Sci. Eng. A, 2020, vol. 786, p. 139419.

14. Z. Hou, P. Hedström, Q. Chen, Y. Xu, D. Wu, and J. Odqvist: CALPHAD, 2016, vol. 53, pp. 39-48.

15. Y. Wu, W. Sun, X. Gao, M. Styles, A. Arlazarov, and C. Hutchinson: Acta Mater., 2020, vol. 183, pp. 418-37.

16. Z. Hou, R.P. Babu, P. Hedström, and J. Odqvist: Mater. Sci. Technol., 2020, vol. 36, pp. 887-93.

17. A. Výrostková, A. Kroupa, J. Janovec, and M. Svoboda: Acta Mater., 1998, vol. 46, pp. 31-38.
18. A. Kroupa, A. Výrostková, M. Svoboda, and J. Janovec: Acta Mater., 1998, vol. 46, pp. 39-49.

19. J. Janovec, M. Svoboda, A. Výrostková, and A. Kroupa: Mater. Sci. Eng. A, 2005, vol. 402, pp. 288-93.

20. M. Rahaman, W. Mu, J. Odqvist, and P. Hedström: Metall. Mater. Trans. A, 2019, vol. 50A, pp. 2081-91.

21. https://www.ferritico.com/. Accessed 10 May 2020.

22. T. Ungár and A. Borbély: Appl. Phys. Lett., 1996, vol. 69, pp. $3173-75$.

23. B. Warren and B. Averbach: J. Appl. Phys., 1952, vol. 23, p. 497.

24. G. Williamson and W. Hall: Acta Metall., 1953, vol. 1, pp. 22-31.

25. T. Shintani and Y. Murata: Acta Mater., 2011, vol. 59, pp. 4314-22

26. S. Takebayashi, T. Kunieda, N. Yoshinaga, K. Ushioda, and S. Ogata: ISIJ Int., 2010, vol. 50, pp. 875-82.

27. S.H. Nedjad and M.R.M. Gharabagh: Int. J. Mater. Res., 2008, vol. 99 , pp. $1248-55$

28. E. Kozeschnik, J. Svoboda, P. Fratzl, and F. Fischer: Mater. Sci. Eng. A, 2004, vol. 385, pp. 157-65.

29. J. Svoboda, F. Fischer, P. Fratzl, and E. Kozeschnik: Mater. Sci. Eng. A, 2004, vol. 385, pp. 166-74.

30. S. Zamberger, L. Whitmore, S. Krisam, T. Wojcik, and E. Kozeschnik: Model. Simul. Mater. Sci. Eng., 2015, vol. 23, p. 055012.

31. S. Zamberger, T. Wojcik, J. Klarner, G. Klösch, H. Schifferl, and E. Kozeschnik: Steel Res. Int., 2013, vol. 84, pp. 20-30.

32. T. Zhou, Z. Hou, R. Prasath Babu, J. Odqvist, and P. Hedström: Materialia, 2020, vol. 9, p. 100630.

33. M. Hillert and J. Ågren: Scripta Mater., 2004, vol. 50, pp. 697-99.

34. B. Sonderegger and E. Kozeschnik: Metall. Mater. Trans. A, 2009, vol. 40A, pp. 499-510.

35. B. Sonderegger and E. Kozeschnik: Scripta Mater., 2009, vol. 60, pp. 635-38.

36. B. Kim, E. Boucard, T. Sourmail, D. San Martín, N. Gey, and P. Rivera-Díaz-del-Castillo: Acta Mater., 2014, vol. 68, pp. 169-78.

37. S. Morito, H. Yoshida, T. Maki, and X. Huang: Mater. Sci. Eng. A, 2006, vols. 438-440, pp. 237-40.

38. M. Roberts: Metall. Trans., 1970, vol. 1, pp. 3287-94

39. A. Shibata, T. Nagoshi, M. Sone, S. Morito, and Y. Higo: Mater. Sci. Eng. A, 2010, vol. 527, pp. 7538-44.

40. Y. Tomita and K. Okabayashi: Metall. Trans. A, 1986, vol. 17, pp. 1203-09.

41. B.B. He, B. Hu, H.W. Yen, G.J. Cheng, Z.K. Wang, H.W. Luo, and M.X. Huang: Science, 2017, vol. 357, pp. 1029-32.

42. S.S. Allain, O. Bouaziz, and M. Takahashi: ISIJ Int., 2012, vol. 52, pp. $717-22$.

43. E. Galindo-Nava and P. Rivera-Díaz-del-Castillo: Acta Mater., 2015, vol. 98, pp. 81-93.

44. K. Nakashima, Y. Fujimura, H. Matsubayashi, T. Tsuchiyama, and S.Takaki: Proc. 1st Int. Symp. on Steel Sci., ISIJ, Tokyo, 2007, p. 215.

45. B. Hutchinson, P. Bate, D. Lindell, A. Malik, M. Barnett, and P. Lynch: Acta Mater., 2018, vol. 152, pp. 239-47.

46. B. Hutchinson, D. Lindell, and M. Barnett: ISIJ Int., 2015, vol. 55, pp. 1114-22

47. M. Saeglitz and G. Krauss: Metall. Mater. Trans. A, 1997, vol. 28 A, pp. $377-87$.

48. N. Kamikawa, Y. Abe, G. Miyamoto, Y. Funakawa, and T. Furuhara: ISIJ Int., 2014, vol. 54, pp. 212-21.

49. T. Zhou, H. Yu, J. Hu, and S. Wang: Mater. Sci. Eng. A, 2014, vol. 615 , pp. 436-46.

50. E. Pavlina and C. Van Tyne: J. Mater. Eng. Perform., 2008, vol. 17 , pp. $888-93$.

51. J. Fu, G. Li, X. Mao, and K. Fang: Metall. Mater. Trans. A, 2011, vol. 42A, pp. 3797-3812.

52. E. Hall: Proc. Phys. Soc., 1951, vol. 64, p. 747.

53. N. Petch: J. Iron Steel Inst., 1953, vol. 174, pp. 25-28.

54. J.S. Wang, M.D. Mulholland, G.B. Olson, and D.N. Seidman: Acta Mater., 2013, vol. 61, pp. 4939-52.

55. B. Wang, Z. Liu, X. Zhou, G. Wang, and R.D.K. Misra: Mater. Sci. Eng. A, 2013, vol. 575, pp. 189-98.

56. H. Wen, T.D. Topping, D. Isheim, D.N. Seidman, and E.J. Lavernia: Acta Mater., 2013, vol. 61, pp. 2769-82.

Publisher's Note Springer Nature remains neutral with regard to jurisdictional claims in published maps and institutional affiliations. 